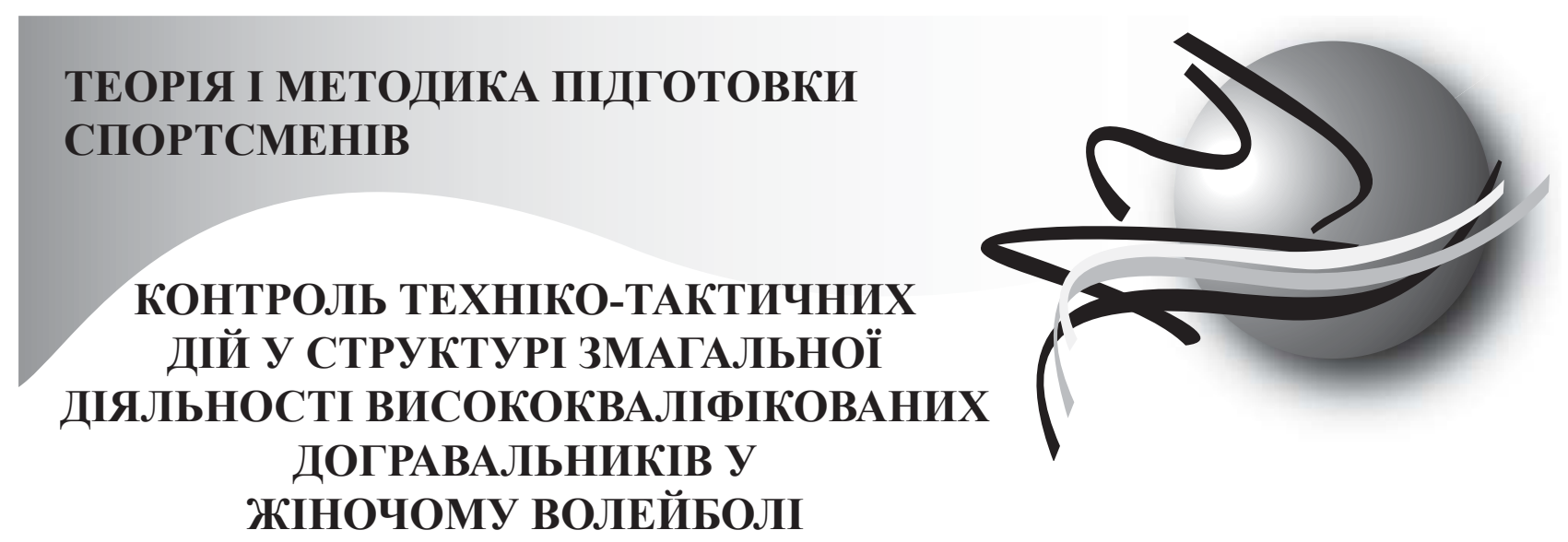

\author{
Щепотіна Наталя, Вознюк Тетяна, Полішук Володимир \\ Вінницький державний педагогічний університет \\ імені Михайла Коцюбинського
}

\title{
DOI: $10.32540 / 2071-1476-2019-4-103$
}

\section{Annotation}

Introduction and purpose. Control is an integral part of the effective management of the training and competitive activities of athletes. It was supposed that studying the structure and dynamics of the performance of technical and tactical actions by highly qualified outside hitters during the match will complement existing data on the features of competitive activity in women's volleyball and will allow for more focused management impacts in the process of training teams of different qualifications. The purpose of the research is to determine the features of the structure and dynamics of the effectiveness of technical and tactical actions of highly qualified female outside hitters of Super League of Ukraine in the process of competitive activity.

Material and methods. The research used methods of analysis of scientific literature, pedagogical observation, mathematical statistics. The competitive activity of 12 highly qualified female outside hitters of the Super League Championship of Ukraine was observed. They had the qualification of a candidate for the master of sports and the master of sports of Ukraine.

Results. The structure of the competitive activity of highly qualified female outside hitters is mostly comprised of the opposite components as a defense actions $(33,1 \pm 3,5 \%)$ and spikes $(29,9 \pm 2,7 \%)$. They are performed by players most effectively $-43,5 \pm 5,8$ and $46,9 \pm 5,8 \%$ respectively. During the game (up to the third set) there is a positive tendency of the attacking components of the game (serves and spikes) and the negative tendency of the defense components (blocks and defense actions).

Conclusions. Two equal parts of the structure of competitive activity of highly qualified female outside hitters contain the opposite components as defence actions and spikes. This shows the universality of the game of the outside hitters. Defence ations are the leading game component for the outside hitters. So, it is necessary to decrease the ratio of ineffective defensive actions, which are $31,9 \pm 6,6 \%$.

Key words: female volleyball players, technical and tactical action, efficiency, defense actions, spike, blocking.

\section{Анотація}

Вступ і мета. Контроль є невід’ємною складовою ефективного управління тренувальною та змагальною діяльністю спортсменів. Передбачалося, що вивчення структури та динаміки ефективності виконання техніко-тактичних дій висококваліфікованими догравальниками впродовж матчу доповнить наявні дані щодо особливостей змагальної діяльності в жіночому волейболі та дозволить здійснювати більш цілеспрямовані управлінські впливи в процесі підготовки команд різної кваліфікації. Мета дослідження - встановити особливості структури та динаміки ефективності виконання техніко-тактичних дій висококваліфікованими догравальниками жіночої Суперліги України в процесі змагальної діяльності.

(C) Щепотіна Н., Вознюк Т.,

Поліщук В., 2019 
Матеріал і методи. У дослідженні використовувалися методи аналізу наукової літератури, педагогічного спостереження, математичної статистики. Дослідження передбачало педагогічне спостереження за змагальною діяльністю 12 висококваліфікованих волейболісток учасників - Чемпіонату України серед жіночих команд Суперліги, які на майданчику виконували функцію догравальника, мали кваліфікацію кандидата в майстри спорту та майстра спорту України.

Результати. Структуру змагальної діяльності висококваліфікованих догравальників найбільше складають такі протилежні за змістом компоненти, як гра в захисті $(33,1 \pm 3,5 \%)$ і нападаючий удар $(29,9 \pm 2,7$ \%), які

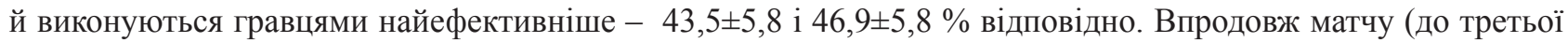
партії) спостерігається позитивна тенденція ефективності виконання атакувальних компонентів гри (подача i нападаючий удар) i негативна тенденція ефективності виконання захисних компонентів (блокування та гра в захисті).

Висновки. Порівняння структури змагальної діяльності догравальників показує, що дві практично однакові частки (по третині від усіх техніко-тактичних дій) складають такі протилежні за змістом компоненти, як гра в захисті й нападаючий удар, що свідчить про їх універсальність гри на майданчику. Оскільки для догравальників саме гра в захисті є провідним ігровим компонентом, потребує зниження показника нефективних захисних дій $(31,9 \pm 6,6 \%)$.

Ключові слова: волейболістки, техніко-тактична дія, ефективність, гра в захисті, нападаючий удар, блокування.

\section{Аннотация}

Введение и цель. Контроль является неотъемлемой составляющей эффективного управления тренировочной и соревновательной деятельностью спортсменов. Предполагалось, что изучение структуры и динамики эффективности выполнения технико-тактических действий высококвалифицированными доигровщиками в ходе матча дополнит имеющиеся данные об особенностях соревновательной деятельности в женском волейболе и позволит осуществлять более целенаправленные управленческие воздействия в процессе подготовки команд разной квалификации. Цель исследования - установить особенности структуры и динамики эффективности выполнения технико-тактических действий высококвалифицированными доигровщиками женской Суперлиги Украины в процессе соревновательной деятельности.

Материал и методы. В исследовании использовались методы анализа научной литературы, педагогическое наблюдение, математической статистики. Исследование предусматривало педагогическое наблюдение за соревновательной деятельностью 12 высококвалифицированных волейболисток-участников Чемпионата Украины среди женских команд Суперлиги, которые на площадке выполняли функцию доигровщика, имели квалификацию кандидата в мастера спорта и мастера спорта Украины.

Результаты. Структуру соревновательной деятельности высококвалифицированных доигровщиков в наибольшей степени составляют такие противоположные по смыслу компоненты как игра в защите $(33,1 \pm 3,5 \%)$ и нападающий удар $(29,9 \pm 2,7 \%)$, которые и выполняются игроками наиболее эффективно - 43,5 $\pm 5,8$ и $46,9 \pm 5,8 \%$ соответственно. В течение матча (до третей партии) наблюдается положительная тенденция эффективности выполнения атакующих компонентов игры (подача и нападающий удар) и негативная тенденция эффективности выполнения защитных компонентов (блокирование и игра в защите).

Выводы. Сравнение структуры соревновательной деятельности доигровщиков показывает, что две практически одинаковые доли (по трети от всех технико-тактических действий) составляют такие противоположные по смыслу компоненты как игра в защите и нападающий удар, что свидетельствует об их универсальности игры на площадке. Так как для доигровщиков именно игра в защите является ведущим игровым компонентом, требует снижения показателя неэффективных защитных действий $(31,9 \pm 6,6 \%)$.

Ключевые слова: волейболистки, технико-тактическое действие, эффективность, игра в защите, нападающий удар, блокирование.

Вступ. Контроль $є$ показники та внести відповідні невід'ємною складовою ефек- корективи до параметрів тренутивного управління тренуваль- вальних навантажень, тактики ною та змагальною діяльністю гри тощо (Bompa, Haff, 2009; спортсменів, адже дозволяє тре- Платонов, 2013; Костюкевич, неру вчасно виявити відстаючі 2016). Доступність педагогічного контролю i, разом з тим, інформативність показників, отриманих з його допомогою, обумовлюють широке застосування саме цього виду контролю в процесі тренувальної та змагальної діяльності 
в ігрових видах спорту (Mitova, Sidorenko, 2015; Вознюк, Драчук, 2016; Kostiukevych, Lazarenko, Shchepotina et al, 2019).

Для ефективної реалізації специфічного принципу єдності та взаємозв'язку структури змагальної діяльності та структури підготовленості (В.М. Платонов, 2013), тренер повинен володіти об'єктивною інформацією щодо особливостей змагальної діяльності гравців волейбольної команди. 3 огляду на це, великий обсяг наукових робіт був присвячений дослідженню обсягу й ефективності техніко-тактичних дій волейболістів (Doroshenko, 2014; Shchepotina, 2015; Стрельникова, Ляхова, 2016), переважному застосуванню тих чи інших тактичних комбінацій у грі (Шльонська, 2015; Imas, Borysova, Shlonska et al, 2017), завантаженості ігрових зон у нападі або захисті (Strelnykova, Liakhova, 2017; Oliinyk, Doroshenko, 2017), особ-ливостей енерговитрат гравців упродовж матчу ( Woodruff, Meloche, 2013; Щепотіна, 2018) тощо.

Динамічний характер розвитку волейболу на сучасному етапі диктує необхідність постійних змін і доповнень до правил, застосування командами відповідних тактичних моделей гри тощо. В контексті вищезазначеного не можна назвати вичерпаними дані, які стосуються особливостей змагальної діяльності висококваліфікованих волейболісток. Зокрема, потребує подальшого вивчення структура та динаміка ефективності виконання техніко-тактичних дій волейболістками високої кваліфікації в процесі змагальної діяльності. На користь цього свідчить і той факт, що висококваліфіковані спортсмени є ідеальними моделями в своєму виді спорту (Byoung-Goo Ko, Ju-Hak Kim, 2005; В.М. Платонов, 2013). Отже, отримані результати можуть використовуватися в якості орієнтира в процесі відбору та підготовки талановитої молоді.

(c) Щепотіна Н., Вознюк Т., Поліщук В., 2019
Дослідження виконано в рамках «Зведеного плану науково-дослідної роботи у сфері фізичної культури і спорту на 2011-2015 pp.» Міністерства України у справах сім'ї, молоді та спорту за темою 2.4. «Теоретико-методичні основи індивідуалізації навчально-тренувального процесу в ігрових видах спорту» (номер державної реєстрації 0112U002001); плану науководослідної роботи кафедри теорії і методики фізичного виховання та спорту Вінницького державного педагогічного університету імені Михайла Коцюбинського на 2016-2020 рр. «Теоретико-методичні основи програмування та моделювання тренувального процесу спортсменів різної кваліфікації» (номер державної реєстрації 0116U005299).

Гіпотеза. Передбачалося, що вивчення структури та динаміки ефективності виконання технікотактичних дій висококваліфікованими догравальниками впродовж матчу доповнить наявні дані щодо особливостей змагальної діяльності в жіночому волейболі та дозволить здійснювати більш цілеспрямовані управлінські впливи в процесі підготовки команд різної кваліфікації.

Мета дослідження - встановити особливості структури та динаміку ефективності виконання техніко-тактичних дій висококваліфікованими догравальниками жіночої Суперліги України в процесі змагальної діяльності.

\section{Матеріал і методи.}

Учасники. Дослідження передбачало педагогічне спостереження за змагальною діяльністю 12 висококваліфікованих волейболісток, які на майданчику виконували функцію догравальника, мали кваліфікацію кандидата в майстри спорту та майстра спорту України.

Організація дослідження. Дослідження проводилося впродовж змагального періоду сезону 2017-2018 pp. і передбачало педагогічне спостереження та відеозйомку офіційних ігор Чемпіонату України з волейболу серед жіночих команд Суперліги. Всього було проаналізовано 11 ігор у рамках регулярного Чемпіонату. Відеозйомку ми здійснювали за допомогою відеокамери «SONY» DCR SX 65 E. В процесі опрацювання відзнятих відеоматеріалів ми здійснювали реєстрацію техніко-тактичних дій волейболісток на спеціально розроблених бланках 3 урахуванням якості їх виконання (Щепотіна, 2017). В подальшому вихідні дані опрацьовувалися за допомогою методів математичної статистики.

Статистичний аналіз. При математичній обробці результатів дослідження використовувалась описова статистика: визначалися середнє арифметичне $(\bar{x})$, середнє квадратичне відхилення (S), стандартна похибка середнього арифметичного (m). Математична обробка результатів дослідження проводилася 3 використанням програмних пакетів MS Excel.

Результати. За результатами педагогічного спостереження було встановлено, що структуру змагальної діяльності висококваліфікованих догравальників у жіночій Суперлізі України в найбільшій мірі складає гра в захисті - у середньому $33,1 \pm 3,5 \%$ за одну партію (рис. 1). Це обумовлено тим, що гравці саме цього амплуа в першу чергу беруть участь у прийомі подачі разом 3 ліберо, в той час як інші гравці «виходять 3 прийому». Близьку за обсягом частку структури техніко-тактичних дій догравальників складає нападаючий удар - 29,9 $\pm 2,7 \%$. В меншому обсязі догравальники виконують блокування $(20,9 \pm 2,5 \%)$, що пояснюється меншим обсягом атак 3 другої зони суперника, проти якого в четвертій зоні грає догравальник.

У процесі реєстрації технікотактичних дій волейболісток ми розглядали три рівні якості їх виконання: 


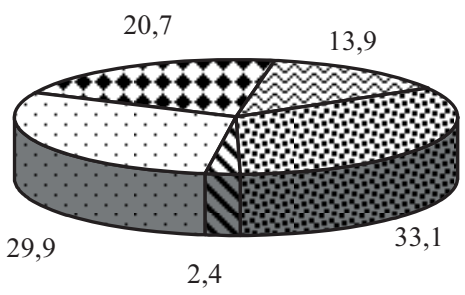

Рис. 1. Частка техніко-тактичних дій у структурі змагальної діяльності висококваліфікованих догравальників у жіночому волейболі в середньому за одну партію, \%:

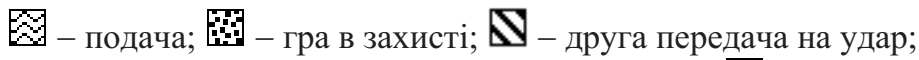

- нападаючий удар (в т.ч. скидка, переведення); - блокування

- «ефективно» - техніко-тактична дія безпосередньо призвела до виграшу розігрування або подальшого вдалого розгортання атаки своєї команди;

- «неефективно» - технікотактична дія безпосередньо призвела до програшу розігрування або зриву атаки своєї команди;

- «позитивно» - техніко-тактична дія не нанесла тактичної загрози супернику, м'яч після iї виконання залишився в грі.

3 огляду на це, на рис. 2 відображено співвідношення ефективних і неефективних технікотактичних дій висококваліфікованих догравальників жіночої Суперліги України - в середньому за одну партію. Аналіз рисунку дозволяє зауважити, що найрезультативніше догравальники вико- нують нападаючі удари і захисні

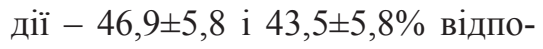
відно. Тобто, найбільш ефективно догравальники виконують ті техніко-тактичні дії, які в найбільшій мірі складають структуру їх змагальної діяльності відповідно амплуа.

Велика частка неефективних захисних дій $(31,9 \pm 6,6 \%)$ загалом відповідає цьому показнику в загальнокомандному аспекті (H. Щепотіна, 2018), однак потребує покращення, оскільки для догравальників саме гра в захисті $€$ провідним компонентом у грі.

Інформативним критерієм змагальної діяльності волейболісток $є$ динаміка ефективності виконання техніко-тактичних дій упродовж матчу (рис. 3). Що стосується атакувальних компо- нентів гри (подача й нападаючий удар), догравальники демонструють позитивну динаміку 3 «піком» у третій партії $(21,1$ і 52,8\% відповідно) і поступовим зниженням ефективності в четвертій (до 16,7 і 44,5\%). Щодо захисних компонентів (блокування та гра в захисті - прийом подач і нападаючих ударів), то в третій партії спостерігається суттєве зниження ефективності виконання блокувань до $34,7 \%$, а гри в захисті - до $31,3 \%$. В четвертій партії ці показники повертаються відповідно до рівня 44,2 і 42,5\%.

Дискусія. Показники висококваліфікованих спортсменів вважаються модельними в певному виді спорту (В.М. Платонов, 2013). 3 огляду на це, представлені особливості структури і динаміки ефективності виконання техніко-тактичних дій догравальниками жіночої Суперліги України в процесі змагальної діяльності здійснюють суттєвий внесок у розвиток теорії і методики підготовки юних і кваліфікованих волейболісток. Отримані дані можуть використовуватися тренерами при розробці прогностичних моделей змагальної діяльності волейболісток, сприяти спортивній орієнтації гравців.

Якщо порівнювати отримані результати 3 даними наших попередніх досліджень щодо струк-

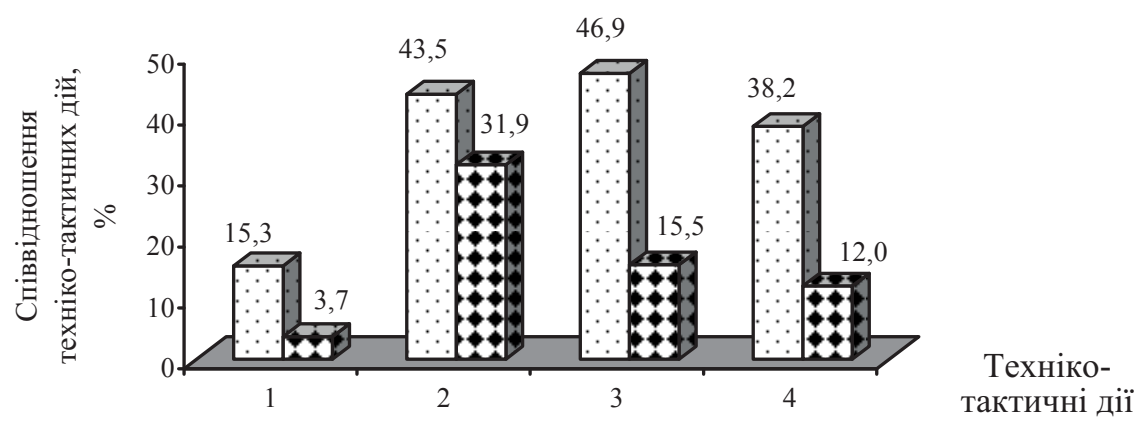

Рис. 2. Співвідношення техніко-тактичних дій висококваліфікованих волейболісток (амплуа догравальник) з урахуванням якості їх виконання в середньому за одну партію, \%:

1 - подача; 2 - гра в захисті; 3 - нападаючий удар (в т.ч. скидка, переведення); 4 - блокування;

$\nabla$ ефективні техніко-тактичні дії; $\square$ неефективні техніко-тактичні діі 


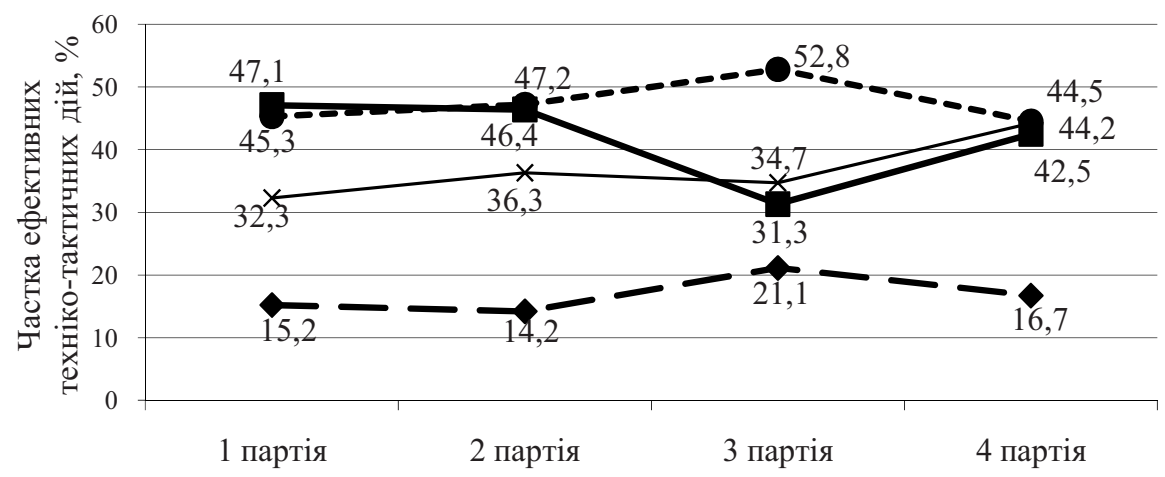

\section{Рис. 3. Динаміка виконання ефективних техніко-тактичних дій висококваліфікованими волейболістками (амплуа догравальник) впродовж гри, \%:

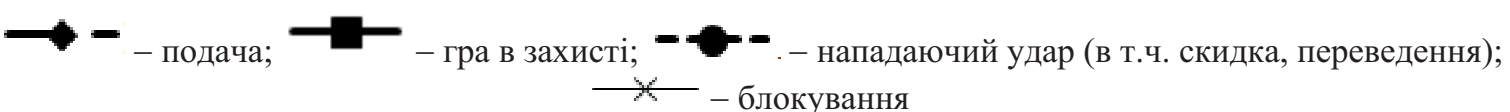

тури техніко-тактичних дій висококваліфікованих діагональних гравців у жіночому волейболі (В. Костюкевич, Н. Щепотіна, В. Поліщук, 2019), то варто відзначити, що догравальники значно менше виконують блокувань і в більшій мірі грають у захисті, порівняно 3 діагональними гравцями.

Порівняння структури змагальної діяльності догравальників показує, що дві практично однакові частки (по третині від усіх техніко-тактичних дій) складають такі протилежні за змістом компоненти, як: гра в захисті й нападаючий удар. Це підтверджує результати попередніх досліджень (О.Л. Шльонської, 2015; Y. Imas, O. Borysova, O. Shlonska et al, 2017) щодо універсальності гри на майданчику догравальників.

Аналіз отриманих результатів дозволяє визначити деякі напрямки підвищення ефективності техніко-тактичних дій висококваліфікованих волейболісток української Суперліги в процесі змагальної діяльності:

перед очною зустріччю необхідним є детальний аналіз моделей гри суперника в атаці та захисті з різними за потенціалом суперниками, що дозволить якісно побудувати оборону та спланувати моделі атакувальних дій;

- значний атакувальний потен- ціал подач обумовлює необхідність їх активного використання проти суперників;

- детальний аналіз статистики проведених матчів за матеріалами DataProject (http://uvf-web. dataproject.com/CompetitionHome. aspx?ID=10) 3 метою роботи над власними помилками;

- розширення моделей можливих комбінацій в атаці та постійне їх варіювання в процесі гри для виведення своїх нападників на атаку або без блоку, або проти неорганізованого блоку суперника.

\section{Висновки.}

1. Аналіз даних наукової літератури довів доцільність використання педагогічного контролю змагальної діяльності в командних ігрових видах спорту для підвищення ефективності управління тренувальним процесом, що обумовлюється доступністю саме цього виду контролю й інформативністю показників, отриманих 3 його допомогою. Ретельно зібрані за допомогою педагогічного контролю дані щодо структури й ефективності змагальної діяльності висококваліфікованих волейболісток можуть слугувати орієнтирами при відборі обдарованої молоді, сприяти спортивній орієнтації гравців, використовуватися тренерами при розробці прогностичних моделей змагаль- ної діяльності волейболісток.

2. За результатами педагогічного контролю змагальної діяльності висококваліфікованих догравальників жіночої Суперліги України було визначено структуру техніко-тактичних дій спортсменок, співвідношення техніко-тактичних дій 3 урахуванням якості їх виконання, динаміку ефективності виконання технікотактичних дій упродовж гри.

Аналіз отриманих даних засвідчив, що:

- структуру змагальної діяльності висококваліфікованих догравальників найбільше складають такі протилежні за змістом компоненти, як гра в захисті $(33,1 \pm 3,5 \%)$ й нападаючий удар $(29,9 \pm 2,7 \%)$, що свідчить про універсальність гравців цього амплуа;

- найефективніше догравальники грають у захисті $(43,5 \pm 5,8 \%)$ та виконують нападаючі удари $(46,9 \pm 5,8 \%)$, які в найбільшій мірі складають структуру їх змагальної діяльності відповідно амплуа;

- ефективність виконання атакувальних компонентів гри (подача i нападаючий удар) упродовж матчу характеризується позитивною динамікою до третьої партії та зниженням їх ефективності в четвертій; щодо захисних компонентів (блокування та гра в захис- 
ті), то до третьої партії динаміка негативна, натомість у четвертій партії ці показники повертаються до вихідного рівня.

Перспективи подалыших досліджень вбачаються в дослід- женні особливостей змагальної діяльності волейболісток різних амплуа та кваліфікації.

\section{Література}

1. Вознюк Т., Драчук А. Контроль змагальної діяльності в баскетболі за часовими інтервалами. Фізична культура, спорт та здоров'я нації: зб. наук. праць. 2016. №. 1. С. 267-271.

2. Костюкевич В.М. Управление тренировочным процессом футболистов в годичном цикле подготовки: монография. 2-е изд.К.: КНТ, 2016. 683 с.

3. Костюкевич В., Щепотіна Н., Поліщук В. Педагогічний контроль техніко-тактичних дій висококваліфікованих діагональних гравців у жіночому волейболі в процесі змагальної діяльності. Фізична культура, спорт та здоров'я нації. 2019. Вип. 7 (26).

4. Стрельникова Є.Я., Ляхова Т.П. Ефективність дій у нападі діагональних гравців у жіночому волейболі. Слобожанський науково-спортивний вісник. 2016. № 2. С. 112-116.

5. Шльонська О.Л. Техніко-тактична підготовка кваліфікованих волейболістів на основі вдосконалення нападаючих дій гравців різного амплуа : автореф. дис. ... канд. наук з фіз. вих. і спорту: спец. 24.00.01 «Олімпійський і професійний спорт». К., 2015. 20 с.

6. Щепотіна Н. Педагогічний контроль фізичних навантажень і техніко-тактичних дій у структурі змагальної діяльності волейболісток. Спортивний вісник Придніпров’я. 2018. № 1. С.92-96.

7. Щепотіна Н.Ю. Педагогічний та медико-біологічний контроль підготовленості та змагальної діяльності волейболісток різної кваліфікації. Теоретико-методичні основи контролю у фізичному вихованні та спорті: монографія; за заг. ред. B.М. Костюкевича. Вінниця ТОВ «Планер», 2017. C. 116-134.

8. Bompa T. O., Haff G. G. Periodization: Theory and Methodology of Training. Champaign, IL, USA: Human Kinetics. 2009. 424 p.

9. Byoung-Goo Ko, Ju-Hak Kim. Physical Fitness Profiles of Elite Ball Game Athletes. International Journal of Applied Sport Sciences. 2005. Vol. 17(1). PP. 71-87.

10. Doroshenko E.Iu. Model parameters of technical and tactical actions in the competitive activities of volleyball players. Physical Education of Students. 2014. Vol. 5. PP. 41-45. doi:10.6084/ m9.figshare.771020.

11. Imas Y., Borysova O., Shlonska O., Kogut I., Marynych V., Kostyukevich V. Technical and tactical training of qualified volleyball players by improving

\section{References}

1. Vozniuk, T., \& Drachuk, A. (2016). Kontrol' zmahal'noyi diyal'nosti v basketboli za chasovymy intervalamy. Fizychna kul'tura, sport ta zdorov"ya natsiyi: zb. nauk. prats' [Control of competitive activity in basketball at time intervals. Fizichna kul'tura, sport ta zdorov'ia nacii], 1, 267-271 (in Ukrainian).

2. Kostiukevich, V.M. (2016). Upravleniye trenirovochnym protsessom futbolistov $\mathrm{v}$ godichnom tsikle podgotovki [Management the training process of football players in the annual training cycle: a monograph]. Kyiv: KNT (in Ukrainian).

3. Kostiukevych, V., Shchepotina, N., \& Polishchuk, V. (2019). Pedahohichnyy kontrol' tekhniko-taktychnykh diy vysokokvalifikovanykh diahonal'nykh hravtsiv u zhinochomu voleyboli v protsesi zmahal'noyi diyal'nosti. Fizychna kul'tura, sport ta zdorov"ya natsiyi [Pedagogical control of technical and tactical actions of highly skilled opposite hitters in women's volleyball in the process of competitive activity]. Fizichna kul'tura, sport ta zdorov'ia nacii, 7 (26) (in Ukrainian).

4. Strelnikova, E.Ya., \& Lyakhova, T.P. (2016). Efektyvnist' diy u napadi diahonal'nykh hravtsiv u zhinochomu voleyboli. [Efficiency of actions in attack of diagonal players in female volleyball]. Slobozhansky Scientific and Sport Herald, 2, 112-116 (in Ukrainian).

5. Shlonska, O.L. (2015). Tekhniko-taktychna pidhotovka kvalifikovanykh voleybolistiv na osnovi vdoskonalennya napadayuchykh diy hravtsiv riznoho amplua [Technical and tactical training of qualified volleyball players on the basis of improvement of attack actions of players of different roles]. Cand. Diss. Kyiv. (in Ukrainian).

6. Shchepotina, N. (2018). Pedahohichnyy kontrol' fizychnykh navantazhen' i tekhniko-taktychnykh diy u strukturi zmahal'noyi diyal'nosti voleybolistok [Pedagogical control of physical activity and technical and tactical actions in the structure of competitive activity of female volleyball players]. Sportivnij visnik Pridniprov'ia, 1, 92-96 (in Ukrainian).

7. Shchepotina, N.Yu. (2017). Pedahohichnyy ta medyko-biolohichnyy kontrol' pidhotovlenosti ta zmahal'noyi diyal'nosti voleybolistok riznoyi kvalifikatsiyi [Pedagogical and medico-biological control of training and competitive activities of volleyball players of different qualification]. Teo- 
attacking actions of players in different roles. Journal of Physical Education and Sport. 2017. Vol. 17. PP. 441-446.

12. Kostiukevych V., Lazarenko N., Shchepotina N., Kulchytska I., Svirshchuk N., Vozniuk T., Kolomiets A., Konnova M., Asauliuk I., Bekas O., Romanenko V., Hudyma S. Management of athletic form in athletes practicing game sports over the course of training macrocycle. Journal of Physical Education and Sport. 2019. Vol. 19 (Supplement issue 1). PP. 28-34. DOI:10.7752/jpes.2019.s1005.

13. Mitova O., Sidorenko V. Control and analysis of dynamics of technical and tactical actions in defence during the game in basketball players of superleague team. Slobozhanskyi herald of science and sport. 2015. Vol. 3 (47). PP. 62-64. https://doi. org/10.15391/snsv.2015-3.011.

14. Oliinyk M., Doroshenko E. Pedagogical characteristics of the systems for assessing the technical and tactical skills of qualified volleyball players. Slobozhanskyi herald of science and sport. 2017. №. 6 (62). PP. 58-62.

15. Shchepotina N.Y. Model characteristics of competitive activity of different skilled female volleyball players. Pedagogics, psychology, medical-biological problems of physical training and sports. 2015. Vol. 2. PP. 80-85. http://dx.doi. org/10.15561/18189172.2015.0214

16. Strelnykova Ye., Liakhova T. Efficiency of actions of the setter in competitions of students' women's volleyball teams of the Kharkiv region. Slobozhanskyi herald of science and sport. 2017. Vol. 1 (57). PP. 73-77. https://doi.org/10.15391/ snsv.2017-1.016

17. Woodruff S.J., Meloche R.D. Energy Availability of Female Varsity Volleyball Players. International Journal of Sport Nutrition and Exercise Metabolism. 2013. Vol. 23 (1). PP. 24-30. doi: 10.1123/ ijsnem.23.1.24. retiko-metodichni osnovi kontroliu u fizichnomu vikhovanni ta sporti: monografiia, 116-134 (in Ukrainian).

8. Bompa, T. O., \& Haff, G. G. (2009). Periodization: Theory and Methodology of Training. Champaign, IL, USA: Human Kinetics.

9. Byoung-Goo, Ko, \& Ju-Hak, Kim (2005). Physical Fitness Profiles of Elite Ball Game Athletes. International Journal of Applied Sport Sciences, 17(1), 71-87.

10. Doroshenko, E.Iu. (2014). Model parameters of technical and tactical actions in the competitive activities of volleyball players. Physical Education of Students, 5, 41-45. doi:10.6084/ m9.figshare.771020.

11. Imas ,Y., Borysova, O., Shlonska, O., Kogut, I., Marynych, V., \& Kostyukevich, V. (2017). Technical and tactical training of qualified volleyball players by improving attacking actions of players in different roles. Journal of Physical Education and Sport, 17, 441-446.

12. Kostiukevych, V., Lazarenko, N., Shchepotina, N., Kulchytska, I., Svirshchuk, N., Vozniuk, T., Kolomiets, A., Konnova, M., Asauliuk, I., Bekas, O., Romanenko, V., \& Hudyma, S. (2019). Management of athletic form in athletes practicing game sports over the course of training macrocycle. Journal of Physical Education and Sport, 19 (Supplement issue 1), 28-34. DOI:10.7752/jpes.2019.s1005.

13. Mitova, O., \& Sidorenko, V. (2015). Control and analysis of dynamics of technical and tactical actions in defence during the game in basketball players of superleague team. Slobozhanskyi herald of science and sport, 3 (47), 62-64. https://doi. org/10.15391/snsv.2015-3.011.

14. Oliinyk, M., \& Doroshenko, E. (2017). Pedagogical characteristics of the systems for assessing the technical and tactical skills of qualified volleyball players. Slobozhanskyi herald of science and sport, 6 (62), 58-62.

15. Shchepotina, N.Y. (2015). Model characteristics of competitive activity of different skilled female volleyball players. Pedagogics, psychology, medical-biological problems of physical training and sports, 2, 80-85. http://dx.doi. org/10.15561/18189172.2015.0214

16. Strelnykova, Ye., \& Liakhova, T. (2017). Efficiency of actions of the setter in competitions of students' women's volleyball teams of the Kharkiv region. Slobozhanskyi herald of science and sport, 1 (57), 73-77. https://doi.org/10.15391/snsv.2017-1.016.

17. Woodruff, S.J., \& Meloche, R.D. (2013). Energy Availability of Female Varsity Volleyball Players. International Journal of Sport Nutrition and Exercise Metabolism, 23 (1), 24-30. doi: 10.1123/ijsnem.23.1.24.

(C) Щепотіна Н., Вознюк Т.,

Поліщук В., 2019 


\section{Щепотіна Наталя}

Вінницький державний педагогічний університет імені Михайла Коцюбинського вул. Острозького, 32, м. Вінниця, 21000, Україна

e-mail: shchepa@mbox.vn.ua

\section{Вознюк Тетяна}

Вінницький державний педагогічний університет імені Михайла Коцюбинського вул. Острозького, 32, м. Вінниця, 21000, Україна

e-mail: tv_vinnitsa@ukr.net

\section{Поліщук Володимир}

Вінницький державний педагогічний університет імені Михайла Коцюбинського вул. Острозького, 32, м. Вінниця, 21000, Україна

e-mail: volodymyrpolishchuk@ukr.net 